\title{
Religiosity and Ecologically Conscious Consumption Behaviour
}

Tajamul Islam

Pondicherry University

Uma Chandrasekaran

Pondicherry University

\begin{abstract}
Religiosity has been found to significantly influence several aspects of consumer buying behaviour. However the area remains considerably under-researched because of the attendant methodological challenges in tackling this sensitive topic. Growing environmental concerns throughout the world have pushed responsible consumption as a critical issue for businesses. This study explored whether religiosity influences the ecological conscious consumption behaviour among consumers in India. A structured questionnaire developed for the purpose of this study was administered to a sample of 191 young Muslim male respondents. Structural equation modelling (SEM) was used to test the influence of two types of religiosities - extrinsic and intrinsic - on ecologically conscious consumption behaviour (ECCB). The results indicated a significant positive relationship between intrinsic religiosity and ecologically conscious consumption behaviour. The findings suggest that religiosity can play an important role in determining ecologically conscious consumption behaviour among Muslim consumers in India.
\end{abstract}

Keywords: Religiosity, Religious affiliation, Muslim consumers, Ecologically Conscious Consumption Behaviour, Indian Consumers, Intrinsic religiosity, Extrinsic religiosity

\section{Introduction}

In the last two decades consciousness towards environmental issues and compliance with ecological standards has become critical for businesses. Issues like global warming, pollution and depletion of natural resources and governmental interventions have made it imperative for firms to reassess their strategies. Green marketing strategies and their potential impact on the triple-bottom line - economic prosperity, environmental quality and social justice - has attracted burgeoning interest among top managers and academicians (Cronin et al., 2011). Strategic actions have evolved from mandatory or voluntary compliance with pollution and energy conservation guidelines to active use of environment friendliness for competitive positioning. This has impelled businesses to identify the characteristics of ecologically conscious consumers in the search for profitable market segments (Do Paco and Raposo, 2009). 
With more products and services entering the green market, it has become an imperative to more accurately profile green consumer segments. The influence of demographics like age, gender, education, social class, marital status etc. on ecological consciousness have been studied to sketch green consumer segments (Diamantopoulos et al., 2003). However, the importance of religion and religiosity as a plausible factor influencing ecologically conscious consumption behaviour has been scarcely investigated.

Religion directly influences consumer choice by laying down the rules of conduct it proclaims and indirectly by contributing to the formation of attitudes and values (Bailey and Sood, 1993). Notwithstanding the enormous and obvious significance, there is a relative dearth of studies on the influence of religion on consumer behaviour. The studies available on the subject however, allude to a considerable role of religion as an influence in the consumer decision making process (Hirschman, 1983; Wilkes et.al, 1986; Bailey and Sood, 1993; Delener, 1994; Sood and Nasu, 1995; Siguaw \& Simpson, 1997; Essoo and Dibb, 2004; Fam et.al, 2004; Mokhlis, 2008; Youngtae Choi, 2010; Zamani-Farahani \& Musa, 2012; Ahmad et.al, 2013; Siala, 2013).

Religion and environment have been intertwined concepts and have inspired a good deal of debate among academicians and followers of different religions. Studies conducted in the context of Judeo-Christian religions suggest that the 'mastery over nature' orientation of religions render their followers less concerned about environmental issues. Highly religious individuals tend to be status quoists and disinclined to take risks (Delenar, 1990; Sood and Nasu 1995: Essoo and Dibb, 2004; Mokhlis 2006). This tendency can be expected to translate to aversion for consumption of green products that usually demand higher innovativeness and propensity for risk taking. Building on this premise, it can be argued that the tendency of ecologically conscious consumption will be relatively lower in highly religious consumers. On the other hand, most major religions, in practice, implicitly or explicitly exhort the importance of a harmonious relationship with the environment (Dwivedi, 1990). In the light of this dilemma, it will be interesting to investigate the influence of religion on ecologically conscious consumption. The degree of religious commitment, termed religiosity, forms the central construct for this study. The objective is to investigate whether religiosity influences ecologically conscious consumption behaviour among young Indian Muslim consumers.

\section{Literature review and hypothesis development}

\section{Religion, religiosity and consumer behaviour}

The significance of religion and religious value systems has long been acknowledged in the disciplines of sociology and psychology but its role in marketing and consumer research is inadequately investigated (Esso and Dibb, 2004). Studies on the influence of religion on consumer behaviour have followed two major approaches: a) comparative impact of different religious affiliations and b) the construct of religiosity - the degree of commitment towards religious practices and principles. One of the earliest studies that attempted to investigate the relationship between religion and consumer behaviour was conducted by Engel (1976) in Brazil. In his empirical study he found sharp differences in the psychographic profiles of two Christian 
denominations and proposed religious affiliation as an important basis for consumer segmentation. Thompson and Raine (1976) found partial support for their hypothesis that a particular furniture store had a greater amount of sales coming from "a middle range of fundamentalist Protestant religious denominations" (p. 71).

Hirschman conducted a series of comparative studies in the early 1980s among Catholics, Protestants and Jews, on various aspects of consumer behaviour. Significant differences were observed among the three religious groups in their evaluation criteria for weekend entertainment, residence selection, transportation and pet selection (Hirschman, 1983). Jewish customers were found to be more innovative, less brand and store loyal (Hirschman, 1981), inherently at a higher level in novelty seeking and information transfer than Catholics and Protestants (Hirschman, 1982).

Wilkes et al. (1986) for the first time employed religiosity as a variable that could affect consumer choice. They concluded that religiosity affects consumer choices through its influence on several consumer lifestyle variables such as opinion leadership, credit purchase, risk avoidance and life satisfaction. McDaniel and Burnett (1990) found commitment to religion or religiosity to be more profound and influential than religious affiliation, on retail store patronage behaviour. In a study on Catholic and Jewish households Delener (1990) found that highly religious individuals tend to perceive higher risks in their purchase decisions than less religious individuals which he attributed to the lack of confidence and security of the highly religious individuals. Sood and Nasu (1995) conducted an exploratory study to examine the effect of religiosity and nationality on consumer behaviour in Japan and America. They observed that devout Protestants had a higher preference for lower priced stores over stores with the best assortment. Moreover, differences were observed between the Japanese and American consumers in their consumption behaviour. The consumer behaviour of Japanese was not affected by religiosity differences, however it did effect the American Protestants.

Essoo and Dibb (2004) found casually religious consumers trendier, more practical, more demanding and more innovative in their shopping behaviour than devout consumers who were more reluctant to try new products, waiting for others to do so first. The study supported the earlier findings by Hirschman (1983) and Sood and Nasu (1995), on the influence of religion on consumer behaviour. Mokhlis (2006) in a study of Malaysian consumers found that religious individuals were more likely to be concerned with price and quality and were less likely to make impulsive purchase decisions. Yountae Choi (2010) found that highly religious South Korean consumers are less likely to switch to another brand, product or store than their less religious and no-religion counterparts. In a study on Malaysian consumers Ahmad et.al, (2013), found that religiosity affected purchase action and product judgement of consumers through a mediating role of animosity and ethnocentric tendencies. Siala (2013) studied Muslim consumers in the UK and offered valuable insights about their consumer behaviour. Devout members among Muslims were found to exhibit high attitudinal loyalty towards a religiously exclusive indemnity service, and the insurer selling the indemnity. These studies reviewed above provide evidence that there is some connection between religion and consumer behaviour. Many of these studies, in general conclude highly religious individuals as more price sensitive, less risk taking, less innovative and tend to avoid switching to new products and brands. 


\section{Religion and Ecologically conscious consumption}

Many socio-demographic factors have been used to profile green consumers for segmentation and targeting. These factors as cited in an interdisciplinary review of literature by Diamantopoulos et al. (2003) include age (Grunert and Kristensen,1992; Scott and Willitis,1994;Van Liere and Dunlap,1980), gender (Davidson and Freudenberg,1996;Schahn and Holzer,1990; Van Liere and Dunlap,1981;Vining and Ebreo,1990), marital status (Honnold,1981; Neuman, 1986), education (Meffert and Bruhn, 1996; Mohai and Twight,1987;Van Liere and Dunlap, 1980), social class (Arbuthnot and Lingg, 1975;Berger,1997; Widegren,1998; Young,1991), number of children (Brooker, 1976; Grunert,1991; Jackson,1983). However, studies on the influence of religious factors on ecologically conscious consumption behaviour are rather scarce.

Lynn White (1967) started a debate on the relationship between the present day ecological crisis and Judeo-Christianity. White argued that the Genesian injunction of Man's dominion over every living being provides a license to brazenly exploit natural resources without any concern for long term repercussions. Hand and Van Liere (1984) corroborated White's view that Judeo-Christians are more committed to a mastery-over-nature orientation that renders them less concerned about environmental problems, than non Judeo-Christians. However, commitment for the mastery over nature orientation varied considerably across different Judeo-Christian denominations. Shaiko (1987) studied a sample of environmental/conservation groups to assess White's theory in a political context. The findings supported White's thesis but also suggested the existence of both stewardship and domination orientations among Judeo-Christians. Eckberg and Blocker (1989) in their study on a sample of respondents from Tulsa, Oklahoma, found substantial support for White's thesis and found that belief in the literal interpretation of the Bible was a significant predictor of lower levels of environmental concern.

On the other hand, the scriptures also emphasize the pro-environmental 'stewardship ethic', which was largely ignored by White's thesis (Kanagy and Willits, 1993; Kanagy and Nelsen, 1995; Kearns, 1997; Shaiko, 1987; Shibley and Wiggins, 1997; Wolkomir et al. 1997a, 1997b; Woodrum and Hoban, 1994; Woodrum and Wolkomir, 1997) as cited by Sherkat \& Ellison (2007) and that there are some studies which find little relationship between religion and environmental concern (Boyd 1999; Greeley 1993; Hayes and Marangudakis 2000, 2001). Most of these studies were conducted on the followers of Christian or Jewish religions. Hardly any studies have been conducted on the followers of other major religions like Islam, Hinduism, Buddhism, Jainism and Shintoism regarding their attitude towards ecological issues.

\section{Intrinsic and Extrinsic religiosity}

In the psychology of religion, one of the most dominant conceptual paradigms is Allport's (1950) 'intrinsic' and 'extrinsic' religious orientations (Brewczynski and MacDonald, 2006). The Allport and Ross (1967) 'Religious Orientation Scale' distinguishes considering religion as an end in itself as Intrinsic orientation versus considering religion as a means to the end as Extrinsic orientation. According to Burris (1999) "extrinsic religiosity refers to endorsing religious beliefs and attitudes or engaging in religious acts only to the extent that they might aid in achieving 
mundane goals such as feeling comforted and protected or acquiring social status and approval, while intrinsic religiosity refers to the motivation arising from goals set forth by the religion itself and is assumed to have an 'otherly', non-mundane, even self-denying quality" (p. 144). For extrinsics the inducement to pursue religious behaviour is driven more by selfish ends. Allport (1966) explained that extrinsically oriented people may be more egocentric, using religion to satisfy ulterior motives such as protection, attention, friendship, social acceptance and comfort. They are not compassionate and caring towards others. It can be argued here that the selfish and self-serving inclination of extrinsics may render them less concerned about ecological issues. Moreover, ecologically conscious consumption demands a certain level of readiness to risk taking, openness to new ideas (Kinnear et al, 1974), a sacrifice in terms of adopting a new product whose performance may not be as good as its nongreen substitute or whose price may be higher and would demand shifting from habitual behaviour (for instance, carrying a cloth bag for shopping etc.). Intrinsics, on the other hand are serious about religious principles and are self-abnegating in religious matters. They are universally compassionate, and believe in brotherhood and sisterhood (Ryckman et al. 2004).

Following from review of literature, we propose the following hypotheses (see Figure 1):

H1: There is a significant and positive relationship between intrinsic religiosity and ecologically conscious consumption behaviour

$\mathrm{H} 2$ : There is a significant and negative relationship between extrinsic religiosity and ecologically conscious consumption behaviour.

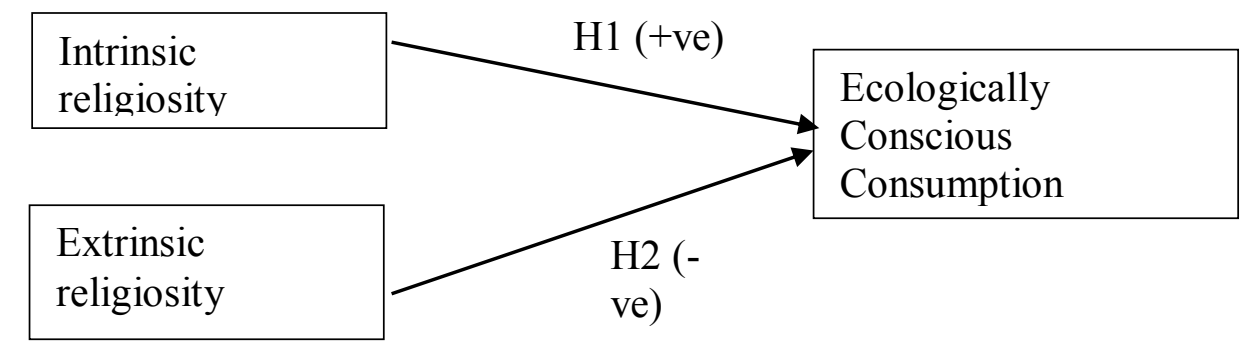

Figure 1: Conceptual Model

\section{Methods}

The study was conducted with a sample of male Muslim respondents in the campus of an Indian university with a diverse population of students from different regions of the country that have a significant Muslim population (Kerala, Tamil Nadu, Jammu and Kashmir, Bihar, Uttar Pradesh and West-Bengal). Allport and Ross (1967) 'Religious Orientation Scale' was modified to suit the Muslim context and a structured questionnaire was developed. Female respondents were excluded. The Extrinsic scale consists of many items pertaining to frequency of visiting the place of worship (Church substituted by Mosque in this study) which are inappropriate in the context of Muslim women, as it is not obligatory for Muslim women to visit the mosque regularly (Khraim, 2010). Besides, women in India do not usually visit 
mosques as there are very few places with mosques that have gender segregated compartments considered a prerequisite for Muslim women. A sample of 200 male students was administered the scale out of which 191 responses were complete and included for final data analysis All the student respondents belonged to the Muslim community and were undergraduate, graduate or doctoral students from different academic disciplines. The age of the respondents ranged from 19 to 30 years, predominantly unmarried and from middle income background with a monthly family income of INR10,000- 50,000.

\section{Measures}

Religiosity. Religiosity is the degree of commitment towards religious teachings and guidelines. A modified version of the 'Religious Orientation Scale' (Allport and Ross, 1967) was used to measure the religiosity level of respondents. The scale has proved highly reliable and has been used in more than 70 studies (Donahue 1985). The 20item ROS scale measures religiosity on the two dimensions of Intrinsic and Extrinsic religiosity, 11 items measuring extrinsic and 9 measuring intrinsic religiosity. The ROS was modified to render it suitable for Muslim respondents. Due to nonavailability of an equivalent replacement, the item 'joining a Bible study group' was dropped. The modified scale thus consisted of 11 items on extrinsic and 8 on intrinsic religiosity. Respondents were asked to rate the items on a 5-point Likert scale anchored 'Strongly agree' (5) to 'Strongly disagree' (1).

Ecologically Conscious Consumption Behaviour. The ECCB construct was measured using a modified version of the 30-item scale used by Roberts' (1996). The behavioural orientation of the ECCB scale eliminates the problem of translation of attitudes into behaviour as widely noted in studies on green marketing on the dichotomy between green attitudes and expressed green behaviours (Straughan \& Roberts, 1999). The scale was modified to suit the Indian context by rephrasing some items. A 5-point Likert scale was used ranging from 'always true' (5) to 'never true' (1) with reverse scoring for negatively worded statements.

\section{Factors and Validity}

Exploratory factor analysis was performed to test the presence of Extrinsic and Intrinsic dimensions of the Religious Orientation Scale. Principal component analysis with varimax rotation was performed. Items having loadings below 0.5 were deleted, which resulted in removal of 9 items. A two factor solution was obtained which explained $62 \%$ of the variance. The two factors consisting of five items each conformed to the extrinsic and intrinsic dimensions of ROS scale. Confirmatory factor analysis (CFA) was used to verify the measurement model for intrinsic religiosity, extrinsic religiosity and ECCB scales. The items that did not load well were dropped. In the final CFA model the 30 item ECCB scale was reduced to 13 items while the 5 items each on intrinsic and extrinsic religiosity scales loaded well and all of them were retained. (see Table 1) 
Table 1: Factors and Loadings on Intrinsic / Extrinsic Religiosity and ECCB

\begin{tabular}{|c|c|c|}
\hline Factor & Items & Loading \\
\hline \multirow{5}{*}{ Intrinsic } & Whole approach to life based on religion & .639 \\
\hline & Religion answers many questions about meaning of life & .776 \\
\hline & Live life according to religious beliefs & .705 \\
\hline & Strong sense of God's presence & .648 \\
\hline & Enjoy reading about my religion & .774 \\
\hline \multirow{5}{*}{ Extrinsic } & Believe in religion, but other things more important in life & .828 \\
\hline & Pray because have been taught to pray & .861 \\
\hline & Go to Masjid to enjoy seeing people I know & .758 \\
\hline & Go to Masjid to spend time with friends & .590 \\
\hline & Going to Masjid helps me make friends & .616 \\
\hline \multirow{13}{*}{ ECCB } & Always choose product that contributes to least pollution & .651 \\
\hline & Tried very hard to reduce amount of electricity I use. & .633 \\
\hline & $\begin{array}{l}\text { Understand potential damage to environment some products cause, } \\
\text { do not purchase these products }\end{array}$ & .724 \\
\hline & Have switched products for ecological reasons & .757 \\
\hline & Buy environmentally friendly products even if higher priced & .642 \\
\hline & $\begin{array}{l}\text { Have convinced family or friends not to buy products harmful to } \\
\text { environment }\end{array}$ & .721 \\
\hline & Have purchased products because they cause less pollution & .724 \\
\hline & Buy products packaged in reusable containers & .752 \\
\hline & Conscious effort to buy products low in pollutants & .779 \\
\hline & Between two products, always buy one less harmful to environment & .769 \\
\hline & Do not buy household products that harm the environment & .717 \\
\hline & $\begin{array}{l}\text { Would buy environmentally friendly product even if price higher } \\
\text { than non-green substitutes }\end{array}$ & .764 \\
\hline & Look for and buy products labelled made from recycled paper & .599 \\
\hline
\end{tabular}

Convergent validity was assessed by observing the factor loadings, average variance extracted and the reliability estimates of the scales (see Table 2). The standardised loading estimates of all the items were higher than 0.5 which is considered acceptable (Hair et.al, 2010). The average variance extracted was calculated for each latent construct. An AVE of 0.5 or higher suggests adequate convergence. The AVE estimates of the ECCB, extrinsic and intrinsic religiosity were found to be adequate. Construct reliabilities for all the three constructs was above 0.7, which suggests adequate reliability. The discriminant validity was assessed by comparing the square root of the AVE estimates of each factor with squared inter-construct correlations associated with that factor (see Table 3). The square root of the AVE estimates was greater than the corresponding inter-construct squared correlations. This indicates adequate discriminant validity of the three constructs (Hair et.al, 2010). 
Table 2: Reliability and Validity

\begin{tabular}{|l|l|l|}
\hline Variables & AVE & Composite Reliability \\
\hline Extrinsic Religiosity & 0.546 & 0.855 \\
\hline Intrinsic Religiosity & 0.505 & 0.835 \\
\hline ECCB & 0.508 & 0.930 \\
\hline
\end{tabular}

Table 3: Discriminant Validity

\begin{tabular}{|l|l|l|l|}
\hline & Extrinsic Religiosity & Intrinsic Religiosity & ECCB \\
\hline Extrinsic Religiosity & $\mathbf{0 . 7 3 9}$ & & \\
\hline Intrinsic Religiosity & 0.062 & $\mathbf{0 . 7 1 1}$ & \\
\hline ECCB & 0.133 & 0.262 & $\mathbf{0 . 7 1 2}$ \\
\hline
\end{tabular}

Note. Diagonal values square-root of AVE greater than off-diagonal values of variance shared (squared correlation) between constructs

\section{Data analysis and results}

Structural equation modelling was performed to test the proposed hypotheses by examining the path coefficients. SPSS Amos (Version 20) was used to perform the analysis using the maximum likelihood estimation method. Various goodness of fit measures were used to test the proposed model and it is evident from the results that the model has achieved acceptable fit (see Table 4).

H1 suggests that intrinsic religiosity has a significant positive effect on ECCB. The path coefficient that measures this relationship between the constructs in $\mathrm{H} 1$ is 0.25 (Significant at $\mathrm{p}<0.01$ ) which confirms the positive effect of intrinsic religiosity on ECCB (see Table 5).

Hypothesis $\mathrm{H} 2$ suggests a negative effect of extrinsic religiosity on ECCB. However the path coefficient that measures this relationship is 0.11 which is not significant. Hence $\mathrm{H} 2$ was not supported. The relationship between extrinsic religiosity and ECCB is not negative, as proposed by the hypothesis. The results indicate a weakly positive but not statistically significant relationship between extrinsic religiosity and ECCB.

Table 4: Goodness-of-fit measures

\begin{tabular}{|l|l|l|l|}
\hline & SEM & Criterion & Reference \\
\hline GFI & 0.91 & $>0.9$ & (Bagozzi and Yi, 1988) \\
\hline AGFI & 0.89 & $>0.9$ & \\
\hline NFI & 0.95 & $>0.95$ & \multirow{2}{*}{ (Hu and Bentler, 1999) } \\
\hline CFI & 0.96 & $>0.95$ & \\
\hline Chi-Square $\mathrm{X}^{2}$ & 508.231 & & \\
\cline { 1 - 2 } Df & 218 & & \\
\hline Relative $\mathrm{X}^{2}\left(\mathrm{X}^{2} / \mathrm{Df}\right)$ & $2.34: 1$ & $3: 1$ & Kline (2005) \\
\cline { 1 - 2 } RMSEA & 0.07 & $<0.07$ & Steiger (2007) \\
& & & \\
\hline
\end{tabular}

Table 5: Results of the SEM model

\begin{tabular}{|l|l|c|}
\hline Relationship & Standardised coefficient & p-value \\
\hline Intrinsic religiosity and ECCB & 0.254 & $0.003^{*}$ \\
\hline Extrinsic religiosity and ECCB & 0.117 & 0.137 \\
\hline
\end{tabular}

Note. ${ }^{*} \mathrm{p}<0.01$ level 


\section{Discussion}

This study indicates support for the hypothesis that there is a significant and positive relationship between intrinsic religiosity and ecologically conscious consumption behaviour. Allport (1966) believed that intrinsically religious individuals take religious principles and teachings very seriously. Intrinsics 'live' the religion and religious goals are more important than all other goals. In Islam, the Holy Quran makes various references to the idea of environmental balance in terms like ' $a d l$ ' meaning justly or equitably, 'qadar' specified measure and 'mizan' balance (Akhter, 1996). The Quran also describes a human being as 'khalifa', which means 'a vicegerent of God on earth', quite similar to the role of stewardship as mentioned in the Bible. Khalifa according to Al-Dhamkhi (2008) is "one who takes over a position, a power, a trust, and who holds it reliably and in harmony with its granter" (p. 16). As a trustee, human beings are supposed to fulfil their duties and responsibilities and are thus accountable for the resources they use. Many teachings of Prophet Mohammad also exhort the judicious use of resources, refraining from wastage, planting of trees and respect for animal rights. It is perhaps, the internalisation of these religious principles by intrinsically religious individuals that makes them more conscious of environmental ethics.

On the other hand many researchers have referred to extrinsics as "using" the religion (Burris, 1999). Extrinsics have a materialistic and utilitarian orientation and use religion as a means of achieving mundane goals, which may result in the relative lack of sensitiveness towards environmental issues. However, the present study could not firmly establish this finding. We could not find any negative relationship between extrinsic religiosity and ecologically conscious consumption behaviour. Extrinsics as defined by Allport (1966) were attributed with negative connotations like immature, selfish and egocentric. However many studies have found them different from the definitions provided by Allport (Ryckman et al.; 2004). Allport (1966) claimed a negative relationship between extrinsic religiosity and willingness to act charitably. Nevertheless, many studies have found extrinsic religiosity to be unrelated to helping behaviour (Batson et al., 1993). In the present study too, extrinsic religiosity did not appear to have much impact on ecologically conscious consumption behaviour. The results did indicate a weakly positive but statistically non-significant relationship, which points out that extrinsic religiosity might perhaps also lead to ecologically conscious consumption behaviour. More importantly the relationship is not negative as suggested by literature. So, we do not rule out the possibility of Extrinsics also behaving in an ecologically conscious manner although the behaviour may be based less on altruistic and more on personal goals like, need for attention and recognition from other members of society. The ROS items that have loaded well in this study seem to indicate that the Masjid is regarded as a place for socialization amongst the Muslim religious community. This in itself can provide potential opportunity for religious group social influence on the individuals as consumers.

The earlier studies that suggested lack of concern towards environmental issues among highly religious individuals were mostly conducted in the western context on Judeo-Christian subjects. As pointed out by these researchers, the 'mastery over nature' orientation of these religions could have been the explanation for this finding. Islam on the other hand emphasizes the 'stewardship' ethic rather than 'mastery over nature'. Islam is the way of life for its followers and it is more than just a religion. 
Fam et.al, (2004) found that Muslims were distinct from the followers of other religion in relation to the advertising of controversial products. To Muslims, the consumption and purchase of products in accordance with religious principles and guidelines is a reflection of obedience and loyalty to their religion. The religious values of justice, balance in nature, frugality and prohibition of wastage, lower materialism and higher spiritualism may explain the positive correlation between intrinsic religiosity and ECCB.

Further, the ECCB scale items that have high loadings indicate a higher moral and ethical ground in terms of active information seeking, willingness to pay a higher price, choosing ecologically better options in the face of other available alternatives and convincing their social groups to adopt more ecologically conscious consumption behaviour. Such a deeper level of relationship can be assumed to originate from one's religiosity and spiritual underpinnings rather than mere demographic factors.

\section{Conclusion and Scope for Future Research}

The present study extends the body of knowledge by including religiosity as a relevant and additional influencer on ecologically conscious consumption behaviour along with the previously reported demographic and psychographic variables. The findings indicate that religiosity can be explored as a possible factor in profiling the green consumer for segmentation purposes. Marketers can consider using religiosity as a segmentation variable in addition to other demographic and psychographic factors. Incorporation of localised religious symbols and values in the marketing communication programs of green products may help in gaining acceptance among consumers. The study included respondents only from the Islamic religion, in order to bring homogeneity and focus and make a beginning in exploring a less researched area. A natural extension would be the inclusion of other religious affiliations with due attention to the methodological complexities.

\section{Limitations}

Although many consumer behaviour studies have used students as proxy for the ultimate consumer, the inclusion of a more heterogeneous and larger sample composed of respondents of different income levels and age groups would lend more statistically robust results and better generalization. Another limitation was the exclusion of female respondents.

\section{Implications for marketing practice}

Religion has been a part of human life since time immemorial. It is one of the most important subcultures that influences the way we perceive things around us, the meaning we give to our surroundings, our judgements and our outlook of the world. Despite its widespread predominance, the role of religion in consumer research has not been extensively investigated. The present study sought to find out whether the degree of commitment towards religion or religiosity can be an influence on ecologically conscious consumption behaviour. The findings indicate that highly religious individuals are ecologically more conscious than less religious individuals. From the marketing point of view, the findings of the study suggest that marketers can use religiosity as a possible segmentation variable to effectively position their 
products. Religiosity and religious affiliation can be used as additional sociodemographic variables to segment green consumers.

Highly religious Muslim societies and countries may offer profound opportunities for green marketers to sell their products. Indonesia, Malaysia, Pakistan, Saudi-Arabia and the GCC countries have Islam as the dominant religion and it plays an important role in consumer lifestyles. Religious messages or symbols can be invoked in advertising and other communication campaigns by marketers to gain acceptance for green products and consumption behaviours among consumers.

The study is also an initial attempt to provide elementary understanding about the consumption behaviour of Indian Muslims who have been insufficiently investigated by market and consumer researchers. India has the third largest Muslim population after Indonesia and Pakistan and constitutes around 11 percent of the total world Muslim population. The investigation of their consumption patterns and behaviour can offer enormous opportunities to domestic as well as international marketers to serve this sizeable consumer segment.

\section{References}

Ahmed, Z., Anang, R., Othman, N., \& Sambasivan, M., (2013), "To purchase or not to purchase US products: role of religiosity, animosity, and ethno-centrism among Malaysian consumers", Journal of Services Marketing, 27(7), 551-563.

Akhtar, M. R., (1996), "Towards an Islamic Approach for Environmental Balance", Islamic Economic Studies, 3(2), 57-77.

Al-Damkhi, A. M., (2008), "Environmental Ethics in Islam: principles, violations, and future perspectives", International Journal of Environmental Studies, 65(1), 11-31.

Allport, G.W., (1950), The Individual and His Religion: A Psychological Interpretation, Macmillian, New York, NY.

Allport, G. W., (1966), "The religious context of prejudice", Journal for the scientific study of religion, 447-457.

Allport, G. W., \& Ross, J. M., (1967), "Personal religious orientation and prejudice", Journal of personality and social psychology, 5(4), 432.

Bagozzi, R. P., \& Yi, Y., (1988), "On the evaluation of structural equation models", Journal of the academy of marketing science, 16(1), 74-94.

Bailey, J. M., \& Sood, J, (1993), "The effects of religious affiliation on consumer behavior: A preliminary investigation", Journal of Managerial Issues.

Batson, C. D., Schoenrade, P., \& Ventis, W. L., (1993), Religion and the individual: a socialpsychological perspective, Oxford University Press.

Brewczynski, J., \& MacDonald, D. A., (2006), "RESEARCH: Confirmatory Factor Analysis of the Allport and Ross Religious Orientation Scale With a Polish Sample", The International Journal for the Psychology of Religion, 16(1), 63-76.

Burris, C. T., (1999), "Religious orientation scale", Measures of religiosity, 144-154.

Choi, Y., (2010), "Religion, religiosity, and South Korean consumer switching behaviors", Journal of Consumer Behaviour, 9(3), 157-171.

Choi, Y., Kale, R., \& Shin, J., (2010), "Religiosity and consumers' use of product information source among Korean consumers: an exploratory research", International journal of consumer studies, 34(1), 61-68.

Cronin Jr, J. J., Smith, J. S., Gleim, M. R., Ramirez, E., \& Martinez, J. D., (2011), "Green marketing strategies: an examination of stakeholders and the opportunities they present", Journal of the Academy of Marketing Science,39(1), 158-174.

Delener, N., (1990), "The effects of religious factors on perceived risk in durable goods purchase decisions", Journal of Consumer Marketing, 7(3), 27-38. 
Delener, N., (1994), "Religious contrasts in consumer decision behaviour patterns: their dimensions and marketing implications", European Journal of Marketing, 28(5), 3653.

Diamantopoulos, A., Schlegelmilch, B. B., Sinkovics, R. R., \& Bohlen, G. M., (2003), "Can socio-demographics still play a role in profiling green consumers? A review of the evidence and an empirical investigation", Journal of Business Research, 56(6), 465480.

Do Paço, A., \& Raposo, M., (2009), “"Green” segmentation: an application to the Portuguese consumer market", Marketing Intelligence \& Planning, 27(3), 364-379.

Donahue, M. J., (1985), "Intrinsic and extrinsic religiousness: The empirical research", Journal for the Scientific Study of Religion, 418-423.

Dwivedi, O. P., (1990), "Satyagraha for conservation: Awakening the spirit of Hinduism", Ethics of Environment and Development: Global Challenge, International Response, 201-12.

Eckberg, D. L., \& Blocker, T. J., (1989), "Varieties of religious involvement and environmental concerns: Testing the Lynn White thesis", Journal for the Scientific Study of Religion.

Engel, J. F., (1976), "Psychographic research in a cross cultural non product setting", Advances in Consumer Research, 3(1).

Essoo, N., \& Dibb, S., (2004), "Religious influences on shopping behaviour: an exploratory study", Journal of Marketing Management, 20(7-8), 683-712.

Fam, K. S., Waller, D. S., \& Erdogan, B. Z., (2004), "The influence of religion on attitudes towards the advertising of controversial products", European Journal of Marketing, $38(5 / 6), 537-555$.

Hair, J. F., Black, W. C., Babin, B. J. \& Anderson, R. E., (2010), Multivariate Data Analysis: A Global Perspective, Seventh Edition, Pearson Education.

Hand, C. M., \& Van Liere, K. D., (1984), "Religion, mastery-over-nature, and environmental concern", Social Forces, 63(2), 555-570.

Hirschman, E. C., (1981), "American Jewish ethnicity: Its relationship to some selected aspects of consumer behaviour", The Journal of Marketing, 102-110.

Hirschman, E. C., (1982), "Religious differences in cognitions regarding novelty seeking and information transfer", Advances in Consumer Research, 10, 228-233.

Hirschman, E. C. (1983), "Religious affiliation and consumption processes: an initial paradigm", Research in marketing, 6, 131-170.

Hu, L. T., \& Bentler, P. M., (1999), "Cutoff criteria for fit indexes in covariance structure analysis: Conventional criteria versus new alternatives", Structural equation modeling: a multidisciplinary journal, 6(1), 1-55.

Khraim, H., (2010), "Measuring Religiosity in Consumer Research From an Islamic Perspective", Journal of Economic and Administrative Sciences, 26(1), 52-78.

Kinnear, T. C., Taylor, J. R., \& Ahmed, S. A., (1974), "Ecologically concerned consumers: who are they?", Journal of marketing, 38(2).

Kline, R. B., (2005), Principles and Practice of Structural Equation Modeling, New York, NY: Guilford.

McDaniel, S. W., \& Burnett, J. J., (1990), "Consumer religiosity and retail store evaluative criteria", Journal of the Academy of Marketing Science, 18(2), 101-112.

Mokhlis, S., (2006), "The effect of religiosity on shopping orientation: an exploratory study in Malaysia", Journal of American Academy of Business, 9(1), 64-74.

Mokhlis, S., (2008), "Consumer religiosity and the importance of store attributes", The Journal of Human Resource and Adult Learning, 4(2), 122-133.

Roberts, J. A., (1996), "Green consumers in the 1990s: profile and implications for advertising", Journal of business research, 36(3), 217-231.

Ryckman, R. M., Thornton, B., Borne, B., \& Gold, J. A., (2004), "Intrinsic-Extrinsic Religiosity and University Students' Willingness to Donate Organs Posthumously", Journal of Applied Social Psychology, 34(1), 196-205. 
Shaiko, R. G., (1987), "Religion, politics, and environmental concern: A powerful mix of passions", Social Science Quarterly, 68(2), 244-262.

Sherkat, D. E., \& Ellison, C. G., (2007), "Structuring the Religion-Environment Connection: Identifying Religious Influences on Environmental Concern and Activism", Journal for the Scientific Study of Religion, 46(1), 71-85.

Siala, H., (2013), 'Religious influences on consumers' high-involvement purchasing decisions", Journal of Services Marketing, 27(7), 579-589.

Siguaw, J. A., \& Simpson, P. M., (1997), "Effects of religiousness on Sunday shopping and outshopping behaviours: a study of shopper attitudes and behaviours in the American South", The International Review of Retail, Distribution and Consumer Research, 7(1), 23-40.

Sood, J., \&Nasu, Y., (1995), "Religiosity and nationality: An exploratory study of their effect on consumer behavior in Japan and the United States", Journal of Business Research, $34(1), 1-9$.

Steiger, J. H. (2007), "Understanding the limitations of global fit assessment in structural equation modelling", Personality and Individual Differences, 42(5), 893-898.

Straughan, R. D., \& Roberts, J. A., (1999), "Environmental segmentation alternatives: a look at green consumer behavior in the new millennium", Journal of consumer Marketing, 16(6), 558-575.

Thompson, H. A., \&Raine, J. E., (1976), "Religious denomination preference as a basis for store location", Journal of Retailing, 52(2), 71-78.

White Jr, L., (1967), “4. The Historical Roots of Our Ecologic Crisis”, Science, 155(3767), 1203-1207.

Wilkes, R. E., Burnett, J. J., \& Howell, R. D., (1986), “On the meaning and measurement of religiosity in consumer research", Journal of the Academy of Marketing Science, 14(1), 47-56.

Zamani-Farahani, H., \& Musa, G., (2012), "The relationship between Islamic religiosity and residents' perceptions of socio-cultural impacts of tourism in Iran: Case studies of Sare'in and Masooleh", Tourism Management, 33(4), 802-814. 